\title{
Afrikaans Business under Apartheid: The Case of the Western Cape
}

\section{Dr. Robert J. Wood}

\author{
Nelson Mandela Metropolitan University, South Campus, University Way, \\ Summerstrand, Port Elizabeth, 6031 \\ rjwood@netactive.co.za \\ Professor R. Haines
}

Nelson Mandela Metropolitan University, South Campus, University Way,

Summerstrand, Port Elizabeth, 6031

richard.haines@nmmu.ac.za

Professor H.R. Lloyd

Nelson Mandela Metropolitan University, South Campus, University Way, Summerstrand, Port Elizabeth, 6031

hendrik.lloyd@nmmu.ac.za

Doi:10.5901/mjss.2014.v5n27p1361

\begin{abstract}
Many commentators have taken a wide-brush view of the effects of apartheid, but the overarching policy's impact on business differed not only on sectoral and ethnic lines, but also from area to area, conspicuously between the Western Cape and the rest of the country (O'Meara, 1982: 167). Despite common assumptions of political marginalization, the Western Cape region was not only the epicentre of Afrikaner capital in the Western Cape, but also politically powerful industries such as the wine industry. However, over time, the large Western Cape Afrikaans-owned conglomerates slowly outgrew the apartheid government, finding increasing common ground with their Anglophone counterparts. In time, this led to tensions with government, despite close ongoing formal and informal contact and communication. This article explores changes in the relationship between Afrikaans business and government in the Western Cape, and how the former moved from being central to outgrowing the apartheid order.
\end{abstract}

Keywords: Western Cape Economy, Apartheid, Afrikaans Business, Sanctions, South Africa.

\section{Introduction}

When considering the impact of apartheid on commerce and industry in the Western Cape, it is important to pay particular attention to the Afrikaner business community in the area; in the region it had most to gain from apartheid. At the same time, however, the relationship between Afrikaans Western Cape business leaders and the apartheid government was not always easy. The more far-sighted members of the Afrikaner community were concerned with long term stability, and, as will become apparent, sometimes favoured reforms that would help promote the creation of a black middle class, creating future social order.

It could be argued that whilst some players disproportionately benefitted from apartheid, most notably, Afrikaner commerce and industry, mining and agriculture, the costs were shared across a wider range of people, with a disproportionate burden being borne by the black majority. Furthermore, the costs were often indirect, spread over many years and ultimately shared by all, even if the benefits were sometimes immediate. These include the persistent dysfunctionality of much of the South African education system and the criminal ecosystem that was nurtured through sanctions busting.

This article reviews the overall rise in the fortunes of Afrikaans business in the early apartheid era; and the development and changes in attitudes and status during the period under review. 


\section{Method}

Primary documents were the foundation of this study. Extensive reference has been made to the archival records of the Cape Town Chamber of Commerce, the $\mathrm{CCl}$ and the Handelsinstituut (the national organisation of Afrikaner business). In addition, other archival sources, such as newspapers, journals and government archival records were examined. In addition, secondary sources were also used, complemented by interviews with Wesgro, the official Destination Marketing Investment and Trade Promotion Agency for the Western Cape, for archival documents. This was supplemented through a systemic search of the secondary and tertiary literature undertaken via keyword searches of the main publishers' online archives; above all, what the latter revealed was that the bulk of the literature on business and apartheid focused on the case of the core region of what is now Gauteng, and/or on selected sectors (above all, the location in the nexus of the minerals-energy-complex and specifically mining, where the Western Cape lacks significant resources). In addition a number of primary sources were interviewed to better understand the Zeitgeist of the time and behaviour of Afrikaans business and the government. These include former editors and journalists, members of government, historians and business owners.

\section{Industrial Policy and the Rise of Western Cape Afrikaans Business}

From 1920 to the end of apartheid, South Africa's industrial policy concentrated on import substitution. Such a policy was common at the time in countries rich in natural resources (Silva, 2007: 67-90), but it also partially arose from the need to provide jobs to solve the 'poor white problem', especially among Afrikaners. The 'poor white problem' refers to the large scale unemployment of whites, particularly Afrikaners, a problem which stretched back to the $19^{\text {th }}$ century, but worsened following the great depression of the 1930s. There was also a desire to replace the imports needed in the mining industry. With the intensification of apartheid and rising international isolation, there would be a stronger emphasis on domestic heavy industry, synfuels, and the defence industry.

Chabane, Goldstein and Roberts (2006) note that state-owned enterprises (SOEs) in the post-1948 period "had three main policy goals: to offset the economic dominance of the gold mining industry, provide some autonomy from foreign producers, and create jobs for Afrikaner workers". This policy included direct assistance to private Afrikaner companies, while interlocking directorships with state corporations gave Afrikaners an inside edge. The subsidiary of Western Cape based conglomerate SANLAM (die Suid-Afrikaanse Nasionale Lewens Assuransie Maatskappij Beperk), Federale Volksbelegging, in particular, benefited from government contracts and subsidies. However, there are many other examples of this, such as the granting of the government contract to print telephone directories to Perskor.

Almost ten years before the National Party was elected to power, in 1939, Afrikaner nationalism took stock of its economic situation at a conference organised by the Federasie van Afrikaanse Kultuurvereenigings (FAK) (Federation of Afrikaner Cultural Associations). A strong sense of the Afrikaner's relative deprivation in relation to other whites, led to the statement that it was necessary to mobilise Afrikaner capital, to 'conquer' the cities, and for Afrikaners to support Afrikaner business. While this approach was criticised as sectional and party-political, the retort was that this was necessary if Afrikaners were to achieve economic self-reliance. The congress also criticised capitalism because it promoted a "spirit of materialism" which Calvinistic Afrikaner culture did not hold in esteem.

The rise of the Afrikaner's economic power was helped by the post-war boom, but the major force was National Party patronage from 1948 onwards through the economic empowerment of Afrikaner interests. Even if apartheid never was fully coherent or functional, its development was at least partially driven by the desire to promote sectional economic interests, even if it would involve compromises with other economic interests. Up until 1948, Afrikaners were not involved to any great extent in commerce or industry in South Africa. In 1946, 30.3\% of Afrikaners were involved in agricultural occupations. This would decline to $16 \%$ in 1960 , and to just $8.1 \%$ by 1977 . The number of Afrikaner 'blue collar' workers remained static throughout the 1950s (40.7\% in 1946 and 40.5\% in 1960), but then dropped precipitously during the boom years of the 1960 s and was a mere $26.7 \%$ by 1977 . Most of the blue collar workers had moved into skilled and better paid positions as can be seen by the marked increase of Afrikaners in white collar categories (29\% in 1946, 43.5\% in 1960 and $65.2 \%$ in 1977)(O'Meara, 1996: 138). What makes this point important is that the underlying composition of a core constituency of the National Party changed: it could be argued that institutions designed to protect or enrich blue collar workers may have been relatively successful, but later, such features became redundant.

Although the reforms of the Botha years represented a change of emphasis from petty apartheid to co-optation and repression, the process was uneven. Some rules and practices - for example, restricting access to marketable skills and training - persisted well after they became largely redundant. The urbanisation of the Afrikaners, together with their movement into more skilled occupations, was a major factor in the improved economic position of the Afrikaners, but their 
businesses received their biggest boost from government's favourable attitude. O'Meara lists four major factors which contributed to the greater stake of Afrikaners in business in South Africa. Firstly, the proliferation of state corporations and parastatals under National Party rule placed Afrikaners in positions of control in key manufacturing sectors. Next, government contracts and subsidies benefited the SANLAM industrial investment subsidiary, Federale Volksbeleggings, in particular. Moreover, the three major Afrikaner financial groups, SANLAM, Old Mutual and Volkskas, began to diversify their holdings, moving into manufacturing in the 1950s. In this case, SANLAM presented itself as the insurance company for Afrikaners in contrast to the Old Mutual's English image. This does not detract from O'Meara's view that the Afrikaner financial sector, in particular, benefited from the actions of the national government. Finally, the drop in share prices and flight of foreign capital following Sharpeville in the 1960s was used by Afrikaner business to increase their shareholdings in a wide range of manufacturing and other companies. This increasing role of Afrikaners in private enterprise is illustrated in Table 1.

Table 1: Afrikaner Percentage Ownership in the Private Sector

\begin{tabular}{|l|c|c|c|c|}
\hline SECTOR & $1948-9$ & $1954-5$ & $1963-4$ & 1975 \\
\hline Agriculture, Forestry and Fishing & 85 & 84 & 83 & 82 \\
\hline Mining & 1 & 1 & 10 & 18 \\
\hline Manufacturing and Commerce & 6 & 6 & 10 & 15 \\
\hline Trade and Commerce & 25 & 26 & 24 & 16 \\
\hline Transportation & $9+$ & 14 & 14 & 15 \\
\hline Liquor and Catering & $20+$ & 30 & 30 & 35 \\
\hline Professions & 16 & 20 & 27 & 28 \\
\hline Finance & 6 & 10 & 21 & 25 \\
\hline Miscellaneous & 27 & 35 & 36 & 45 \\
\hline Aggregate & 24.8 & 25.4 & 26.9 & 27.5 \\
\hline Aggregate excluding Agriculture & 9.6 & 13.4 & 18.0 & 20.8 \\
\hline
\end{tabular}

+ Estimates

Source: O'Meara, 1996: 137

It is apparent from the above table that the major beneficiaries in the Afrikaner business community during the apartheid years were those involved in the financial, industrial and commercial sectors, with Cape interests dominating in key sectors. In the 1960s, Afrikaner finance consisted basically of two groups: Cape-based SANLAM and its numerous subsidiaries and the Transvaal-based Volkskas. The large increase in Afrikaner involvement in the mining industry followed on the transfer of General Mining by the Anglo American Corporation to SANLAM's subsidiary Federale Mynbou.

\section{The Western Cape Situation}

In the early years of the apartheid government, the Afrikaner business community had a positive attitude to government policies. This was emphasised by Dr C.R.Louw, the chairman of SANLAM. He said in his chairman's address to the 1962 annual general meeting of SANLAM that, notwithstanding the attacks from within and without South Africa, the economy had grown remarkably. The country's gold and foreign reserves had also increased. He commented that of the 61 companies in which SANLAM had invested, 46 had shown an increase in profits, while the profits of 15 had declined for the year ending 30 June 1961. Calculated on the shareholders' interest in these companies during the same period, 33 companies reflected an increase, while 28 showed a decrease. This was remarkable in the light of what had occurred in South Africa - a referendum on the republican status, followed by withdrawal from the Commonwealth with the loss of preferential treatment for its exports to Britain, as well as racial unrest. In addition, there was the drop in gold and foreign reserves following disinvestment by foreigners. Despite all these negative factors, in the view of Dr Louw, there was nevertheless stability in the political and economic spheres (Louw, 1962: 1-4).

The Cape-based Rembrandt Group grew rapidly after 1948, becoming one of the world's major tobacco corporations; it also had very substantial liquor and other holdings, both locally and overseas. The predominantly Afrikaner-controlled Cape liquor industry also boomed after 1948 (O'Meara, 1996: 140). Rembrandt benefited from the National Party government, even though Anton Rupert, the chairman and founder of the Rembrandt Group, had a very stormy relationship with Prime Minister Verwoerd in the 1960s. Rupert was of the view that it was essential that blacks be given the opportunity to own houses in white urban areas, to give them a stake in the status quo, a suggestion to which 
Verwoerd reacted violently. Rupert then modified his suggestion to one of a 99-year lease, but this incensed Verwoerd. He never forgave Rupert and never again spoke directly to him. Verwoerd had previously had an unfortunate experience with an investment, and accordingly did not trust capitalists (O'Meara, 1996: 71).

Again, this would highlight some of the internal contradictions of the system. Whilst the intention of the apartheid government was to promote Afrikaner economic interests, there was also hostility in some government quarters to them becoming so large as to approximate English-speaking capital. There is evidence that even some direct beneficiaries of apartheid were gradually becoming aware of its indirect costs at the same time as becoming more capable of independence. Rupert's relationship with Verwoerd's successor, B.J. Vorster, was considerably easier, but Rembrandt's progress must have been adversely affected by the conflict (Dommisse and Esterhuyse, 2005: 157). Rupert was again critical of the Bantustan policy, introduced by Verwoerd which, in his view, more than anything else led to poverty in South Africa, and hence, social instability. Rupert favoured white investment in black areas, which became another source of conflict (Dommisse and Esterhuyse, 2005: 163).

The government's policy of import substitution and the establishment of parastatals in the Pretoria, Witwatersrand and Vereeniging (PWV) area, together with apartheid legislation, adversely impacted on economic growth in the Western Cape. The parastatal nearest to Cape Town was the Mossgas factory built in the late 1980s producing petrol from the natural gas fields of Mossel Bay; but this lay outside the Western Cape area. Ton Vosloo, editor of prominent Afrikaans newspapers and a director of SANLAM, commented in an interview that the Western Cape had little industry apart from fruit and wine (Interview with Vosloo on 17.4.2012). However, the head offices of the two major life insurance groups, Old Mutual and SANLAM, were situated in Cape Town, signifying that Cape Town had considerable financial clout in the Afrikaans-speaking business community. Note how in Table 2 Cape Town exceeds Pietermaritzburg-Durban in bank deposits circa 1972.

Table 2: Indicators of the Spatial Allocation of Privately Owned Capital Stock (Cape v. Other Centres)

\begin{tabular}{|l|c|c|c|c|}
\hline & \multicolumn{3}{|c|}{ Percentage of Total in 1972 } \\
\hline Spatial Area & $\begin{array}{c}\text { Machinery and Equipment in } \\
\text { Manufacturing }\end{array}$ & $\begin{array}{c}\text { Mortgage Bonds } \\
\text { Registered Value) }\end{array}$ & $\begin{array}{c}\text { Bank } \\
\text { Deposits }\end{array}$ & $\begin{array}{c}\text { Population } \\
(1970)\end{array}$ \\
\hline Pretoria-Witwatersrand & $47 \%$ & $37 \%$ & $56 \%$ & $19 \%$ \\
\hline Durban-Pietermaritzburg & $21 \%$ & $11 \%$ & $7 \%$ & $7 \%$ \\
\hline Cape Metropolitan & $7 \%$ & $9 \%$ & $13 \%$ & $6 \%$ \\
\hline Total & $75 \%$ & $57 \%$ & $76 \%$ & $32 \%$ \\
\hline Other Areas & $25 \%$ & $43 \%$ & $24 \%$ & $68 \%$ \\
\hline
\end{tabular}

Source: 1972 International Census and 1970 Population Census Reports and Bureau of Market Research (1972A) Cited in: Nattrass, Jill, The South African Economy (1981), p.95

\section{High and Late Apartheid}

The Afrikaner business community in the Western Cape was adversely affected in some areas by apartheid; but it can be argued that the benefits they received from the government in the period from 1960 to 1990 more than compensated for this. Afrikaner business boomed during this period. Key Afrikaner business interests outgrew the system, and were increasingly reluctant to remain subordinate to the political line of the ruling party. Perhaps, in some way, apartheid adversely affected SANLAM, but the patronage of the Nationalist government was such that it boosted the company to impressive heights.

Reflecting the "outgrowing process", the attitude of SANLAM's management to government policies was, however, marked by change during the apartheid years, as indicated by two vastly different Chairman's addresses to the SANLAM board in 1962 and 1964. First, in Dr Louw's address at the 1962 AGM where he referred to the remarkable growth of the economy in spite of limitations, he also referred to 'separate development', the term then being used by the government regarding its apartheid policies. He said that the government was aware of the necessity of expanding and consolidating the Bantustans as soon as possible (Louw, 1962: 6). By the time of his Chairman's Address at SANLAM's 1964 AGM, Dr Louw was referring to inflationary pressures which had arisen in the economy and to the increasing overseas concern as to the impact of apartheid on the South African people and its economy; yet he also drew attention to the improvement in the conditions of the non-whites in South Africa (Louw, 1962: 4).

However, the Chairman's Address to SANLAM's 1986 AGM, given by Dr F.J. du Plessis was not as confident as 
those of his predecessors. He said that the South African economy had not performed in a satisfactory manner, and that growth was low, showing the largest fall since the days of the great depression in the 1930s, inflation was at $18 \%$ at the end of 1985; and that the exchange rate of the rand had sharply declined. The significance of these dates is worth noting. During 1985 and 1986 there was widespread mass-based resistance to the National Party government's policies, while increasingly repressive actions were taken by the state in an attempt to preserve the status quo.

While the current account of the balance of payments reflected a record surplus due to the fall in the rand exchange rate, the capital account was a serious problem and South Africa faced a currency crisis. The country was experiencing weak international demand for its products and falling export prices, inter alia, for key minerals. The latter is corroborated by statistical evidence which demonstrates the extent to which the collapse of the gold price in the 1980s mirrored the crisis and decline of apartheid (see Figure 1).

Figure 1: Changes in the Real and Nominal Gold Price

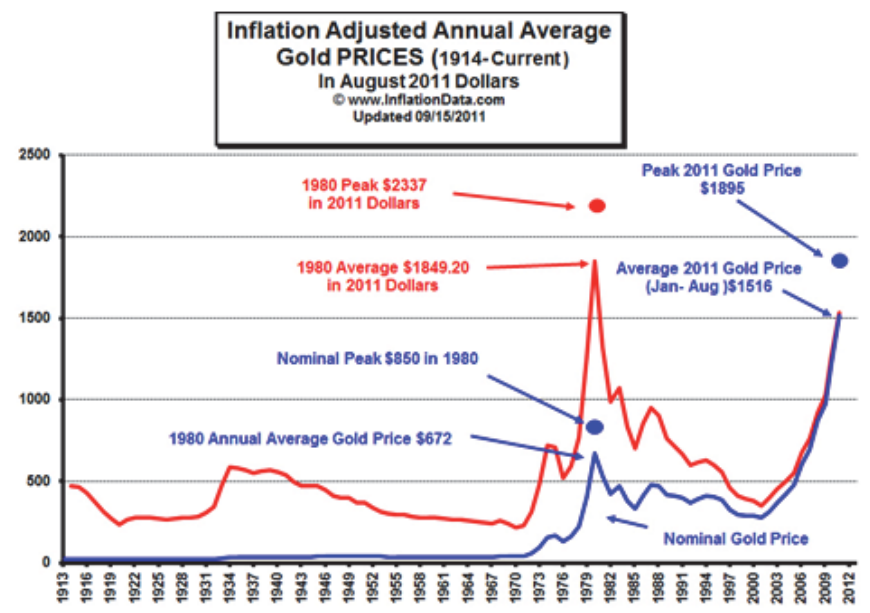

Source: (http://inflationdata.com/Inflation/images/charts/Gold/Gold_inflation_chart.htm)

Notably, this matches the collapse of South African exports in figure 2. In short, the apartheid government was not providing Afrikaner big business with the stable economic environment it needed.

Figure 2: Changes in South African GDP (GDPPCKUS), Consumption (CPCUS) and Exports (XPCKUS) per capita

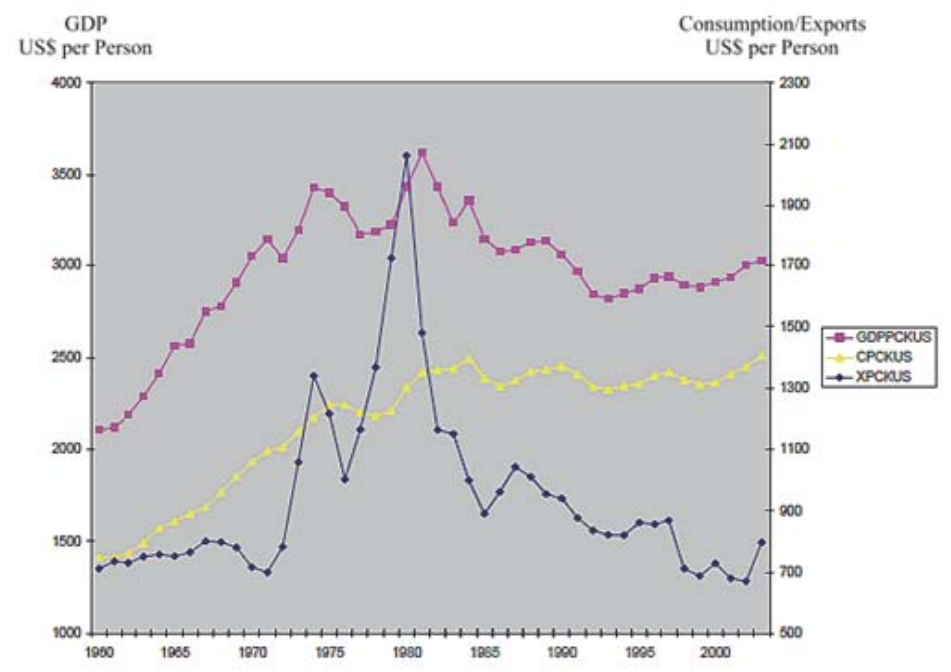

Source: Dube et al., 2007, p.6. 
In Du Plessis's (1986) view, South Africa had not attracted sufficient overseas investments and was having to turn to short-term overseas loans, a resort that would cause considerable problems when overseas banks refused to roll over these loans. Although the fall of the rand was at least partially due to developments in primary commodity markets (see the above chart on changes in the real gold price), the perceived link between the decline of the rand and Botha's reluctance to deliver on real reforms had a far reaching impact on international business confidence in the country. Du Plessis also spoke of the inflationary impact that the rising wages for black people was having on the economy and called for a national strategic plan to deal with the increasing danger of overseas sanctions and boycotts (1986: 3).

The mood in Afrikaner business had changed. The same Du Plessis, in his role as president of the Urban Foundation, in an address to its AGM on 31 January 1986, referred to the fact that the pendulum of South Africa's fortunes seemed to have been "permanently stuck at its negative extremity". As Du Plessis's report to the Urban Foundation stressed, the situation had become more serious in 1985, referring to a range of government's actions mainly attacks on neighbouring countries and increased violence at home, as well as the Rubicon speech by President Botha on 15 August 1985 - that undermined faith in the sincerity of its intention to reform. Du Plessis found it hard to accept that all these events were simply coincidental. There were two conflicting theories: firstly that the government's actions were being undermined by right-wing elements; and secondly that the government's insistence that reform could only take place by negotiation with those black leaders who renounced violence was merely a facade behind which the government would sporadically fuel existing tensions to minimise the chances of negotiations getting under way. What is clear was that the ruling party, and its support-base, was increasingly divided. Militarists appeared to be often unconcerned about adverse economic or political developments, whilst large Afrikaans business interests were increasingly more concerned about stability and economic opportunities than preserving racial domination (Adam and Moodley, 2003). The overseas business sector was confused and this increased the 'hassle factor' of doing business in South Africa.

In his chairman's address to the 1988 AGM of SANLAM, Dr F J du Plessis referred to President Botha's announcement that South Africa could only achieve a just and stable political future if the economy were sufficiently robust to deal with the economic consequences of achieving this object. Botha's statement could be seen as a rhetorical departure from his earlier cavalier attitude towards entreaties for reforms in the interests of economic growth, and, in turn, perhaps reflected the extent of the realignment in Afrikaner economic power. Conceivably, Afrikaner businessmen no longer were firmly subordinate to government, but, rather, the latter were increasingly compelled to take the lead from the former. In contrast to their approach in 1962, SANLAM management had, by 1988, realised that change had to come, that apartheid had not provided a viable solution to South Africa's problems, and that the economy could no longer afford the cost. There was a wide change in attitude by both the English and Afrikaans speaking business community and this was evidenced by the business delegation led by Gavin Relly which met the African National Congress in 1985. By 1981 eight conglomerates controlled more than $60 \%$ of the assets in the private sector. Four years later, four of these conglomerates had been taken over by the big four: Anglo American, SANLAM, Old Mutual, and Rembrandt. These four together controlled over $80 \%$ of the shares listed on the Johannesburg Stock Exchange, with the Afrikaner economic movement being led by SANLAM and Rembrandt (Dommisse, Esterhuyse, 2005: 177). Clearly, the nature of Afrikaner economic interests had fundamentally changed: they were increasingly dominated by large conglomerates that were necessarily more outwardly orientated in line with their expansion. Here, it is worth emphasizing that both SANLAM and Rembrandt were Cape-based. One might draw political conclusions from this; the Afrikaner political elite in the Western Cape was closely aligned with the Afrikaner business dominating the region, whereas the Afrikaner political elite in the Transvaal was historically suspicious of the Anglophone mining interests dominating the region.

\section{Corruption}

When considering the economic conditions that characterised the 1980s, another issue worth discussing is the existence of corruption at state level and in the business sector, prevalent during the final decades of National Party governance, and the extent to which this contributed to South Africa's economic predicament during this period.

Gerald Shaw, former Cape Times journalist, said, in his interview, that no empirical data is available as to the extent of corruption in the apartheid period. However, by the close of the period under review, an increasing number of cases were made public. Examples from the 1980s included the trial of Minister Piet du Plessis for corruption and Minister Fanie Botha's resignation under suspicious circumstances (Interview with Shaw on 4.4.2007). Confirming this, Vosloo said that during the period under review there was corruption. For instance, Cabinet Minister Jan Haak gave fishing quotas to friends and Members of Parliament. Two Deputy Ministers, Hennie van der Walt and Pietie du Plessis, were involved in a scandal in 1964, when they purchased land at a cheap price and resold it to the government for an 
international airport, making a large profit for themselves.

In the 1960s, Broederbond infiltration of agricultural cooperatives and the Land Bank would ensure that political considerations would predominate in credit allocation. These forms of patronage and favouritism were mainly geared towards promoting Afrikaner nationalism and at their inception involved no personal gain. Even as late as the mid-1970s, J.N.Cloete, director of the South African Institute for Public Administration, maintained that the controls in the civil service were so stringent that bureaucrats had "little opportunity to use patronage and the conferment of financial benefits for the achievement of improper objectives" (Lodge, 1998: 158-159). Significantly, he did not deny the existence of patronage, but simply maintained that it was deployed for political purposes rather than for personal profit.

Vosloo of Naspers regarded the leadership of the National Party of this period as men of integrity and he supported the government in the newspapers he edited - he knew Verwoerd, Vorster and P W Botha all personally (Interview with Vosloo on 17.4.2012). This view was also corroborated by Professor Giliomee (Interview with Giliomee on 31.3.2007). (Like Vosloo, Giliomee is a staunch Afrikaner nationalist, although from a perspective critical of the late National Party.) When the apartheid regime's policies were softened under President Botha (undermining ethnic solidarity), and a consumerist outlook spread in the Afrikaner community, there was an increase in corruption. However, the Afrikaner establishments could no longer discipline their employees on the basis of allegiance to the volk (Interview with Giliomee on 31.3.2007). As the ideological clarity of the past had been lost, it could be argued that solidarity within the Afrikaner community had weakened: large Afrikaner firms had increasingly little in common with small Afrikaner business, class gradually overwhelming ethnic solidarities.

In support of this point of view, Terreblanche refers to the "corrupt wheeling and dealing between the private and public sectors in the 1980s and early 1990s". He also states:

We can argue that the crisis of the apartheid regime (+-1974-1990) was also a crisis of racial capitalism and the white corporate sector. In their struggle to survive, both the white political establishment and a large part of the white business establishment became involved in all sorts of criminal and corrupt activities (Terreblanche, 2002: 405).

For most of the time corruption was covered up, in contrast to the present-day situation, where corruption is widely reported on by the media, Terreblanche argued. Shaw said that apartheid had left a legacy of low moral standards, and observed that the culture of corruption continued under the new dispensation, and that business ethics had deteriorated. In other words, the late apartheid order established clear precedents - and mechanisms - for corruption amongst political elites. It can also be argued that it was not just the elite that were corrupt. In the apartheid years, respect for the law declined in the light of the repressive, unjust, and illogical laws introduced. Shaw quoted the words of George Soros, the prominent and well known financier, who said that self-interest had been elevated to become a moral principle (Interview with Shaw on 4.4.2007).

However, other commentators have different views. For instance, Lodge (1998: 158-159) said that: "Even outside the mysterious world of covert operations, though, central government departments seem to have had a history of routinised corruption". Specific irregularities included fictitious tenders and the subsequent award of tenders to spouses, the receipt of gifts by officials in return for contracts, and payments to firms for imaginary work and materials. Over the years, several hundreds of millions of Rands were lost through various forms of nepotism and fraud in a department which administered about $11 \%$ of the national budget (Lodge, 1998: 158-159).

Dr D. F. Malan and his successors as Prime Minister and/or President vigorously promoted Afrikaner rent-seeking, often within the bounds of legality. This included providing jobs for Afrikaners, awarding government contracts to Afrikaner enterprises, and vastly extending Afrikaner dominated parastatals. This led to an influx of poorly qualified Afrikaners, particularly at lower levels, and a decline in service levels and professionalism in the public service. Illegal corruption was restrained in the earlier years of apartheid, in the light of the belief of senior public servants that they were serving the volk (the Afrikaner community) (Hyslop, 2005: 781-783). The political scandal known as the Information Scandal, or Muldergate, involving the Department of Information, led to the fall in mid-1979 of State President John Vorster. The Erasmus Commission was appointed to investigate the scandal. The late Judge R.P.B. Erasmus, in his report, referred to the scandal in the following terms:

The purpose of the Information Department's secret fund had all the attraction of a lovely fresh apple, but the germ which could cause complete rot to set in was already there in the flowering stage because of lack of clarity in the existing statutory control (O'Meara, 1996: 241).

The scandal involved an attempt to promote a more favourable view of the government both internally and externally. However, these efforts were costly and ham-handed. Inter alia, a distinctly dull and narrow minded "international news magazine", To the Point, was founded at great expense. There were a number of similarly inept efforts, most notably, a bizarre attempt to develop a South African counterpart to Hollywood around a derelict power station in Mossel Bay, which served more to highlight the parochialism and political naivety of their initiators than to 
meaningfully impact on social attitudes. Somewhat more durable proved to be the Citizen newspaper, which may have promoted a more favourable view of the government amongst English speaking whites, albeit at a time when the internal dynamics of white politics were coming increasingly irrelevant (Van Zyl Slabbert, 2003). All this was very costly, and opened up numerous opportunities for self-enrichment. When R13 million was loaned to Louis Luyt to start a newspaper, most of the loan was later invested in Luyt's companies (O'Meara, 1996: 241). The Afrikaner political and corporate elite was clearly no longer automatically pursuing the interests of the bulk of the Afrikaner population. Increasingly, the security services - and above all, the military - took the lion's share of covert funds, rather than conventional government bureaucrats (Davis, 1987).

Large sums of money continued to be siphoned off in this period to promote South Africa's image abroad, at a time when the economy was stagnating. Sanctions-busting was commonplace, which usually required some form of bribery of foreign officials or businesspeople; the Western Cape became a major centre of this activity. Those taking part in this were free from scrutiny by the South African media and parliament since sanctions-busting was assumed to be patriotic. However, since it involved largely unsupervised private enterprise there was considerable scope for private profit. The official secrecy which was maintained to evade oil sanctions masked extensive venality. In 1984 John Malcomess of the Progressive Federal Party suggested that government officials, responsible for procuring oil, were "creaming off something for themselves". This led to a symbiotic relationship between corrupt government officials and dubious foreign businessmen; many of the latter set up shop in the Western Cape owing to its agreeable climate and relative safety from extradition. Prominent among them were Marino Chiavelli, Marc Rich and Vito Palazollo.

In the mid- 1990s, it became clear that Marino Chiavelli had brokered with apartheid officials a covert deal that allowed for the import of Saudi oil (Mail and Guardian 13 October 1995). Chiavelli had a record of dubious business dealings in Italy, and went on to short change his commercial partners in South Africa (Sunday Times 12 September 2010). Another prominent oil sanctions buster, Marc Rich, was later indicted in the US for tax evasion and sanctions busting to Iran, prior to being controversially pardoned, allegedly for services to Mossad (Ammann, 2009). The search for arms and the need to launder money led to growing links with overseas criminal networks, including the Sicilian Mafia, which brought with it further temptation for officials to skim off some of the invisible money flows. Such members included Vito Palazollo, who was convicted in Italy of involvement with the Sicilian Mafia (Mail and Guardian, 19 November 1999).

\section{The KWV}

If the preceding sections have highlighted some of the costs of apartheid to business, let us now consider a key beneficiary of the system. The size and impact of the KWV (Koöperatieve Wijnbouwers Vereniging van Zuid-Afrika Bpkt) merits its consideration in its own right. Up until the late 1980s, manual skills and technology as well as relatively low cost labour made cheap bulk wine production in the Western Cape not only possible but also profitable, because the cooperative known as KWV ran a system of legally binding quotas allocated to farmers, whereby they were guaranteed a fixed price for their predetermined production quota regardless of quality. This was, of course, an example of limited complementarity; the low quality meant that this system of production was only sustainable in a controlled market, and through the fact that KWV and its affiliates, Stellenbosch Farmers Winery and Bergkelder, enjoyed an oligopolistic position in the domestic wine market. This does not mean that their wine was always of good quality, but that their products sold because there was limited choice available in the local market. Protectionism meant that most local consumers were unaware of the relative quality of South African wine vis-a-vis overseas producers, and were insulated from major international developments in the wine industry. Michael Fridjhon, former chair of the South African Wine Industry Trust, comments:

Isolation meant that producers lost a real sense of the global market. Wine styles and variety selection suffered as a result. The KWV was the only real conduit to the export market - which meant that SA brands had a very limited chance of building their own brand image. KWV also controlled the supply of plant material (Written Response to Questionnaire, 17.2.2012).

The issue of the poor condition of South African grape stock throughout the 1980 s reflected the distribution of virus infected rootstocks (Powell, 2012: 8). Although the boom of wine exports following on the demise of apartheid is clearly in part due to the end of sanctions and consumer boycotts, a range of independent sources confirm that the wine industry is now coping very much better with shifts in international tastes (Ponte and Ewart, 2007: 17-18).

Estates seeking to produce and market wine independently of KWV were subject to many difficulties and constraints (Dietrich, Fiske, McAlister, Schobe, Silverman and Waldron, 2004: 38-40). Moreover, the wine exported was often of very poor quality. Fridjhom cites an incident that occurred when the KWV sent surplus wine to Europe (Michael Fridjhom, Email on 16.2.2012). Much of this bulk wine found its way to Bulgaria, where it was bottled and labelled as 
Bulgarian produce for sale in UK supermarkets: as a result, Bulgarian wine enjoyed a brief prominence in the UK market, and was acclaimed by consumers and critics alike for its value and perceived quality, tropical and heat treatment. Nor did the creativity stop here: bulk wine was also carbonated, and sold as French champagne (Michael Fridjhom, Email on 16.2.2012). Even more remarkable than the creativity of the sanctions busters was the apparent acceptance by large numbers of Western consumers of the results as the genuine product. These episodes may have opened all manner of opportunities for personal enrichment. These malpractices were finally exposed by a whistle-blower within the KWV (Michael Fridjhom, Email on 16.2.2012).

Anthony Hamilton Russell, winemaker, whose father pioneered the independent production and marketing of wine using Pinot Noir and Chardonnay, globally acclaimed cultivars then largely denied to the South African market in defiance of KWV quotas and strictures, commented that the regulation system in the industry was in his view reasonably successful in servicing the interests of bulk producers, even if independent players suffered (Anthony Hamilton Russell, Interview on 14.2.2012). It sustained the industry, keeping it viable. Meanwhile, a fixed minimum price guaranteed income (Anthony Hamilton Russell, Interview on 14.2.2012). However, with time the industry proved itself unable to adapt to changing circumstances in the market. Other interviewees expressed doubts as to the performance of the late apartheid wine industry. For example, Robert Kaplan said that the poor economic performance of the Western Cape in the closing years of apartheid was influenced by the decrease in export earnings from fruit and wine. This impacted on his company's profitability (Interview with Kaplan on 1.11.2011).

\section{Discussion}

According to a former prominent (Anglophone) businessman, Hans Middelmann, central to the rise of the South African economy in the 1950s and 1960s was the significant contribution made by the "brilliant" Afrikaner industrialists, bankers, and businessmen, together with the rank and file of the Afrikaner population, to the South African economy. Afrikaners made up the base of this economic development, which had previously been mainly a British initiative. In Middelmann's words: "The...severance of Commonwealth ties put the final seal on these achievements" (Cape Times 26.10.1976). This contribution was nurtured and supported by close relations with government for most of the apartheid era.

However, it seems evident that early apartheid was much more conducive to the economic interests of most Afrikaners than late apartheid. Quite simply, much of Afrikaner business outgrew apartheid; early organisations established to empower the community at large developed into great conglomerates. Such organisations were no longer content to remain the subordinates of political leaders, but rather increasingly had political interests and economic concerns of their own. Above all, they were increasingly concerned with political stability, market access and domestic and international commercial ties, and less with ethnic solidarity. This would echo Regulation Theory's point that institutions constructed to serve and support particular economic interests and growth trajectories may, after a period of time, no longer effectively do so (Jessop, 2001: xiv). In other words, institutions can only provide temporary mediation and as a result of both external pressures and the choices of individuals and social actors, institutional arrangements come under pressure and eventually break down. This process was characterized by eroding internal solidarities: increasingly powerful militarists in government were less concerned with economic growth than big Afrikaans business was; and small Afrikaner business and employees had less in common with the owners of the great Afrikaans conglomerates.

This would confirm the relevance of Regulation Theory's - and, indeed, other strands of comparative institutional analysis such as Business Systems Theory's - emphasis on the nature of, and changes to, the social relations interlinking firms and other players (Jessop, 2001: $x$-xv). Finally, economic activity encompasses not only legitimate behaviour but also criminality. Late apartheid was highly conducive both to the emergence of new criminal networks and to the appropriation of some state functions for criminal purposes. The operation of such networks was again contingent on personalized ties and relations within the ruling party. Over time, however, even this dimension was characterized by incoherence.

Finally, it would be incorrect to say that the only economic interests served by apartheid were Afrikaans. The utility of the migrant labour control system - developed prior to apartheid, but refined and expanded under it - to the mining industry is well documented (Wolpe, 1976: 425-456). Although mineral revenues helped fund an increasingly wasteful system, they also cemented the fortunes of the country to destabilize commodity markets. Again, this would confirm Resource Curse Theory's argument that mineral revenues may encourage complacency and waste among governments. 


\section{Conclusion}

On the one hand, there is little doubt that a broad range of Afrikaans businesses benefited indirectly and directly from the support and patronage of the apartheid state. However, once their position was established, some prominent Afrikaans business leaders became increasingly concerned as to the long term consequences of apartheid in terms of political stability. More specifically, the change in the sentiment in the Afrikaner business community in the 1980s was due to the deteriorating economic situation in South Africa as well as the concern that the government did not have an answer to the country's political, social, and economic problems. The optimistic views of Afrikaner business in the 1960s had evaporated, and they were fearful of what the future would hold. At the same time, the ideological waters became muddied by the Botha government's half-hearted reforms, and as a consequence of sanctions busting and the opportunities opened by the security forces' 'dirty tricks', a new class of criminal entrepreneur emerged in the 1980s. Again, this highlights the extent to which an institutional order developed at least in part to serve Afrikaner economic interests and increasingly failed to serve its intended functions, necessitating, as suggested by Regulation Theory, a protracted period of institutional tinkering and experimentation.

Since the two main Afrikaner conglomerates - together with Anglo-American and Old Mutual - controlled some 80\% of Johannesburg Stock Exchange shares by 1985 were Cape-based the economic empowerment of Afrikaners had a strong regional dimension. The Western Cape was the area with the main concentration of big Afrikaner business, which, over time, had interests increasingly at odds with the apartheid government. This regional bias towards comparative literalism is likely to have reflected, at least in part, the composition and sectoral coverage of such conglomerates.

\section{References}

Adam, H. And Moodley, K. The Opening of the Apartheid Mind. (Berkeley, 2003).

Ammann, D. 2009. The King of Oil: The Secret Lives of Marc Rich. London: St. Martin's Press.

Bunting, B. The Rise of the South African Reich (London, 1986).

Business Day (Johannesburg) 3 June 2002. "Politics of the Cape a Cesspool".

Cape Times (Cape Town) 26 October 1976. "Integration must be Acknowledged".

Chabane, N., Goldstein, A., and S. Roberts. "The Changing Face and Strategies of Big Business in South Africa: more than a decade of political democracy". Industrial and Corporate Change. (15: 3) (2006), pp. 549-578.

Hall, P. and Soskice, D. An Introduction to the Varieties of Capitalism. In P. Hall and D. Soskice (eds.), Varieties of Capitalism: The Institutional Basis of Competitive Advantage, Oxford: Oxford University Press (2001).

Davis, S.M. Apartheid's Rebels: Inside South Africa's Hidden War (New Haven, Yale, 1987). Dietrich, K., Fiske, C. McAlister, K., Schobe, E., Silverman, I. and Waldron, A., "To Raise a Toast: Grain and Grape in the Swartland, South Africa-Trends, Causes and Implications of Agricultural Land Use Change", A report sponsored by the Department of Environmental \& Geographical Sciences at the University of Cape Town, under the auspices of the 'Globalisation \& the Natural Environment' Programme, Cape Town (2004).

Dommisse, E. and W. Esterhuyse. 2005. Anton Rupert: A Biography. (Cape Town, 2005).

Dr F.J. du Plessis, Chairman's Address to SANLAM's 1986 AGM.

Dr F.J. Du Plessis, President's Address to the South Africa Foundation Annual Minutes of General Meeting on 31.1.1986.

Dube, O., Hausman, R. and D. Rodrik. 2007. "South Africa: Identifying the Binding Constraint on Shared Growth". Unpublished mimeo.

Grundlingh, A. "Are We Afrikaners Getting too Rich?" Historical Sociology (21:2-3) (2008), pp. 143-165.

Hyslop, J. "Political Corruption Before and After Apartheid". Journal of Southern African Studies. (31:4) (2005), pp. $773-789$.

Jessop, B. "Series Preface - The Parisian Regulation School", Jessop, B. (ed.), Regulation Theory and the Crisis of Capitalism - Volume 1) (Cheltenham, 2001).

Inflationdata.com. "Inflation Adjusted Gold Price" (2012). Available at: http://inflationdata.com/Inflation/images/charts/Gold/Gold_ inflation_chart.htm

Lodge, T. "Sanctions and Black Political Organisations". In Orkin, M. (ed.), Sanctions Against Apartheid. (London, 1989).

Lodge, T. "Political Corruption in South Africa". African Affairs. (97) (1998).

Louw, E. The Rise, Fall and Legacy of Apartheid. (Westport, 2004).

Louw, C.R. Chairman's Address to SANLAM's 1962 AGM.

Louw, C.R. Chairman's Address to SANLAM's 1964 AGM.

Mail and Guardian (Johannesburg) 19 November 199. "Palazollo: The Mobster from Burgersdorp".

Mail and Guardian (Johannesburg) 13 October 1995. "How Chiavelli Earned his Tax Free Millions".

Nattrass, J. 1981. The South African Economy: Its' Growth and Change. Cape Town: Oxford University Press.

Powell, Northwest College, Comparison between Grape Growth Techniques and Wine Production between the Republic of South Africa and the United States of America. (Powell, 2012).

O'Meara, D. Forty Lost Years: The Apartheid State and the Politics of the National Party, 1948 - 1094. (Randburg, 1996). 
O'Meara, D. Volkskapitalisme (Cambridge, 1982).

Ponte, S. And Ewart, J. "South African Wine: An Industry in Ferment", TRALAC Working Paper, 8, (2007).

Ross, M. "The Political Economy of the Resource Curse". World Politics (51) (January 1999), pp. 297-322.

SANLAM, Annual Reports 1980 \& 1990.

SAPA (Johannesburg). 22 December 2013. Palazollo Deported to Italy.

Seattle Times (Seattle) 31 March 2012. "Italian Held in Thailand on Alleged Mob Ties.

Silva, E. "The Import Substitution Model". Latin American Perspectives (34:3) (2007), pp. 67-90.

Sunday Times (Johannesburg). 12 September 2010. "Marino Chiavelli".

Terreblanche, S. A History of Inequality in South Africa, 1652-2002. (Pietermaritzberg, 2002).

Van Zyl Slabbert, F.. The Other Side of History: An Anecdotal Reflection on Political Transition in South Africa (Johannesburg \& Cape Town, 2003).

Welsh, D. "Political Economy of Afrikaner Nationalism". In Leftwich, A. ed.) South Africa: Economic Growth and Political Change. (London, 1974).

Whitley, R. Divergent Capitalisms: The Social Structuring and Change of Business Systems (Oxford, 1999).

Wolpe, H. "The White Working Class in South Africa", Economy and Society (5: 2) (1976), pp. 197-240.

\section{Interviews}

Professor Hermann Giliomee on 31.3.2007. (Historian)

Gerald Shaw on 4.4.2006. (Former Cape Times journalist)

Robert Kaplan on 1.11.2011. (Managing Director: Capegate)

Michael Fridjhom, Written Response to Questionnaire on 17.2.2012. (Wine Correspondent and Author)

Anthony Hamilton Russell on 14.2.2012. (Proprietor: Hamilton Russel Vineyards)

Ton Vosloo on 17.4.2012. (Senior Executive: Naspers) 